\section{The Manual of}

\section{Official Procedure of the Government of}

\section{Canada: An Exposé}

\author{
Nicholas A. MacDonald
}

James W.J. Bowden *

\section{Introduction}

In light of the much discussed issue to "codify" or make an official interpretation of constitutional conventions in Canada, this article introduces the Manual of Official Procedure of the Government of Canada to further stimulate discussion on the topics presented at the Public Policy Forum and at the David Asper Centre for Constitutional Rights in 2011. ${ }^{1}$ It also posits that constitutional conventions derive from principles rather than existing in isolation. This article is part of a larger, forthcoming work in the Journal of Parliamentary and Political Law.

In 1968, Henry Davis and André Millar of the Privy Council Office produced the Manual of Official Procedure of the Government of Canada under the direction of Prime Minister Lester B. Pearson.

\section{The Manual of Official Procedure of the Gov- ernment of Canada has been prepared to fill a long-recognized need for quick and thorough guidance on the many constitutional and pro- cedural issues on which the Prime Minister, individual ministers or the Government must from time to time exercise discretion and judgement. ${ }^{2}$ - Lester B. Pearson}

The Manual examines the principal elements of government, states the legal position in given situations, and identifies the considerations relevant to decision and discretion in particular circumstances. Precedents are described and evolution outlined. Administrative procedures are defined and representative documents are included as sources or examples. ${ }^{3}$
At the time of its production, no other Commonwealth country had produced a handbook on conventions that paralleled the Manual's breadth and depth-a staggering 1,500 pages over two volumes. Pearson hoped that this Manual would "be of valuable assistance to [his] successors in the Office of Prime Minister and to all those directly responsible for the process of government in Canada." ${ }^{3} \mathrm{He}$ expected that it would be expanded to cover additional areas and practices arising from evolving laws and customs. ${ }^{5}$ While sources have noted that the Privy Council Office today considers the Manual lacking in nuance, dated, and incorrect in its interpretation of some conventions, it is still consulted from time to time as a reference.

Presented here are excerpts taken from the Manual relating to the conventions and protocols governing the formation of governments, the uses of prorogation and dissolution, and the principle of restraint (often referred to as the "caretaker convention"). Although we cover only three topics, the Manual contains an array of topics under broad headings, including Cabinet, Elections, Government, the Governor General, the House of Commons, Judges, Lieutenant Governors, Ministers, Parliament, Prime Minister, and the Sovereign. Each main topic is broken down into five categories: (1) a general "position", (2) "background" on relevant historical precedents and case studies, (3) required "procedures", (4) required "Ceremonies" (if any), and (5) relevant references to appropriate appendices. 
First, however, a brief discussion of the nature of "constitutional conventions" is in order.

\section{On Principles, Convention, and the Challenges of Writing the Unwritten}

The Constitution of Canada has been defined by the Supreme Court of Canada as "the global system of rules and principles which govern the exercise of constitutional authority in the whole and in every part of the Canadian state." Constitutional conventions are unwritten political norms, which evolve from practices and customs. These unwritten conventions complement and contextualize the written constitution. More fundamentally, constitutional conventions are the manifestations of constitutional principles that underpin them and provide their normative justification. It is when constitutional conventions no longer conform to their corresponding principle that their purpose is questioned.

British constitutional scholar Sir Ivor Jennings proposed that a custom or practice exists as a convention if it satisfies three criteria: What are the precedents? Do the actors believe they are bound by a rule? Is there a reason for the rule? ${ }^{7}$ However, if constitutional conventions are the manifestations of more fundamental constitutional principles such as responsible government, then the validity or soundness of a convention could be ascertained based on whether it conforms to constitutional principles.

Conventions can change or be modified relatively quickly and as needed. Principles, in contrast, evolve slowly through history, and change only in response to significant episodes of political strife, civil unrest, or armed conflict. A few examples are the barons' rebellion and the resultant Magna Carta (1215); the English Civil War (1642-1651) and the Glorious Revolution (1688) with the resultant English Bill of Rights; and, in Canada, the Rebellions of 1837 and the resultant Durham Report and right of responsible government.

Unwritten principles and conventions can be more powerful and persuasive than written rules. Rather than relying on the coercive force of law, convention encourages good behaviour through self-restraint and moral obligation out of respect for the constitution and parliament. Indeed, this understanding of "trust" or "good faith" is vital to the success of unwritten conventions. This British approach to constitutionalism is entirely different from the conception that underpins the American Constitution, which embodies the idea, as James Madison famously described in the Federalist Papers, that "Ambition must be made to check ambition."

In the Quebec Secession Reference, the Supreme Court of Canada identified four constitutional principles in Canada from which constitutional conventions could derive their normative justification: federalism, democracy, constitutionalism and the rule of law, and the protection of minorities. ${ }^{9}$ On the democracy principle, the Court wrote:

[T] he democracy principle can be best understood as a sort of baseline against which the framers of our Constitution, and subsequently, our elected representatives under it, have always operated. It is perhaps for this reason that this principle [of democracy] was not explicitly identified in the text of the Constitution Act, 1867 itself. To have done so might have appeared redundant, even silly, to the framers. ${ }^{10}$

As with the democracy principle, other principles and conventions were also presumed.

In Canada, these constitutional principles and conventions are as much a part of the Constitution as the Constitution Act, 1867 and the Constitution Act, 1982. As the Supreme Court of Canada has recognized: "constitutional conventions plus constitutional law equal the total constitution of the country."11

The preamble of the Constitution Act, 1867 incorporates unwritten constitutional conventions into our overall Constitution, which is "similar in Principle to that of the United Kingdom." 12 Although conventions are politically enforceable and therefore not justiciable, the Supreme Court has established that courts can nonetheless make rulings based on convention even if they cannot enforce conventions themselves: 
It should be borne in mind however that, while [conventions] are not laws, some conventions may be more important than some laws. Their importance depends on that of the value or principle which they are meant to safeguard. Also they form an integral part of the constitution and of the constitutional system. [...] That is why it is perfectly appropriate to say that to violate a convention is to do something which is unconstitutional although it entails no direct legal consequence. [emphasis added $]^{13}$

Responsible government now functions as the keystone of constitutional convention and secures the democratic principle in the Westminster parliamentary system: the people elect a House of Commons of their representatives, and the House of Commons determines who forms the government. Responsible government developed in order to forge an unbreakable link between Parliament and the government, and through this link the government derives its legal authority to govern by commanding the confidence of the House of Commons. When the House withdraws its confidence, the government falls. The written constitution codifies neither this convention, nor the fundamental principle of democracy necessary for parliamentary government. Canada has nevertheless benefited from responsible government since $1848 .{ }^{14}$

This article presents three sections on conventions and protocols from the Manual of Procedure of the Government of Canada: on the formation of governments, the uses of prorogation and dissolution, and the principle of restraint. The Manual succinctly presents not only the conventions themselves; it also presents the more important, why, such conventions exist. (The quoted sections preserve the original paragraph numbering, therefore some of the paragraphs are not in their original order. They also come from the five separate categories described above, which restarts the numbering in some places).

\section{On Government Formation}

The Manual discusses the appointment of the prime minister:
1. The Prime Minister is chosen by the Governor General when the position becomes vacant. Convention dictates that if a party has a majority in the House of Commons its leader must be selected. If there is no majority party the Governor General seeks the leader of the party able to command support from a majority in the House.

2. In Canada the Governor General is bound by convention to accept the leader selected by the party and does not make his own choice from amongst the members.

3. Advice to the Crown by the Prime Minister before resignation has, in Canada, been looked upon as a normal state of affairs, but constitutional opinion clearly indicates that the Crown, in exercising its prerogative in selecting a Prime Minister, is theoretically under no obligation to take the advice of the Prime Minister. In practice, of course, the Crown may have little alternative. For example, "Where the Government is defeated and there is a leader of the Opposition the King must send for him."15

[...]

1. The discretion of the Governor General in selecting a Prime Minister is exercised within the limits of his position as representative of a constitutional monarch. He is looking for a Prime Minister who will be supported by a majority in the House of Commons and whose advice he will accept as long as he retains his confidence.

\section{$[\ldots]$}

2. The uncertainty which in Canada surrounds the question of advice by a Prime Minister about his successor arises in part from failure to distinguish the situations before and after resignation. In 1926, Mr. King's hypothesis that he "...might have advised His Excellency to send for some other hon. Member of this House to form an administration," clearly referred to the alternative advice to dissolution which would have been given before his resignation. When he did not resign on dissolution being refused there is no reference to any advice regarding his successor. In 1930 Mr. King announced on 29 July that he had advised the Governor General to 
send for Mr. Bennett. He did not resign until August 6. In 1944, when considering resignation, he was again speaking of advice before resignation and in reply to a question by the Governor General. ${ }^{16}$

$[\ldots]$

1. The appointment of a Prime Minister becomes effective when, in response to the invitation, he informs the Governor General that he is in a position to form a Government. This is usually conveyed orally without formality. ${ }^{17}$

[...]

1. The formal initiative in selecting a new Prime Minister is with the Governor General. Except in the most unusual circumstances there will be no doubt as to the person to be called since the parliamentary situation or the electoral result will have made the designation clear. ${ }^{18}$

\section{On Prorogation and Dissolution}

The Manual distinguishes between the summoning and prorogation of parliament, on the one hand, and dissolution on the other:

1. The Governor General takes the operative steps, on the advice of the Prime Minister, to summon, prorogue and dissolve Parliament.

2. The Governor General accepts the Prime Minister's advice on summoning and proroguing Parliament.

3. On dissolution the Governor General retains a degree of discretion and is entitled to satisfy himself that dissolution recommended by the Prime Minister is justified under Canadian constitutional practice. A decision by the Governor General not to accept the advice to dissolve Parliament would, however, amount to a withdrawal of his confidence in the Prime Minister and could involve immediate and serious problems, as was demonstrated in $1926 .{ }^{19}$

These distinctions are justified through an analysis of both the Macdonald-Dufferin prorogation of 1873 and the King-Byng Affair of 1926:
1. The Governor General does not retain any discretion in the matter of summoning or proroguing Parliament, but acts directly on the advice of the Prime Minister. This was not always so. In 1873 the Governor General, [Dufferin], met with the Privy Council to lay before the Government '... the terms on which he would accede to a prorogation of Parliament..., but this is now of historic interest only. ${ }^{20}$

2. In regard to dissolution the preponderant constitutional opinion appears to be that in certain circumstances the Governor General still retains some discretion, even after the 1926 crisis. Those events did not eliminate the Governor General's discretionary right to decline the advice to dissolve but served to bring out the extremely limited circumstances in which the possibility of declining the advice of the Prime Minister could be entertained. ${ }^{21}$

As to the appropriate length of the intersession at prorogation:

6. It is custom for Parliament to be on summons and therefore it is always prorogued to a certain stated date, even if there is no firm intention that it meet on that date. If no date for meeting for business is selected, Parliament is prorogued for a period of 40 days and summoned pro forma to meet on a stated date at the termination of that period. The period of prorogation is extended by issuing proclamations for periods of 40 days. When it is desired to open a new session a proclamation summoning Parliament to meet on a stated date "for the dispatch of business" is issued. ${ }^{22}$

The rationale for this 40-day intersession is:

12. A 40-day period was fixed by the Great Charter of King John as the minimum notice for summoning Parliament, and although this has been modified in England by statute, it has come into Canadian usage as the customary period for pro forma prorogation. ${ }^{23}$

Finally, the Manual acknowledges that, as of 1968, there was no consensus on the circumstances in which the governor general could invoke the reserve power to reject advice to dissolve: 
4. The proclamation to dissolve is issued by the Governor General on the advice of the Prime Minister.

5. The Governor General retains certain discretion whether to accept the advice to dissolve. $^{24}$

\section{$[\ldots]$}

6. The circumstances in which the Governor General would be justified in rejecting this advice have been the subject of searching and inconclusive examination by constitutional authorities, particularly in relation to the Byng-King case of 1926. It can be said nevertheless that discretion does exist; Churchill and Atlee amongst others have both made clear statements on this point.

7. Dissolution leads to a general election with the consequent interruption of the routine of government. So the basic argument is that in certain circumstances the Governor General need not accept the advice if a general election would not be in the public interest. This implies that an alternative Government could be formed which could command a majority in the House of Commons so that the government of the country can be continued without resorting to an election, and that no new major issue of national policy has arisen which should be put before the electorate.

8. The Byng-King crisis and the subsequent election results did not bring to an end the Governor General's discretion regarding dissolution; it remains to be used in those rare and almost indefinable circumstances when it is necessary for the protection of the constitution. ${ }^{25}$

\section{The Principle of Restraint}

Often referred to as the "caretaker convention", the Manual codified this principle as "Restraints on Business which may be transacted by Governments in Certain Circumstances:"

1. A Government receives its authority from the Crown and is responsible to Parliament for the exercise of that authority. As long as a Government remains in of- fice its legal authority is unimpaired and its obligation to carry on the government of the country remains, whether Parliament is dissolved or not. The necessity to account to Parliament for the exercise of this authority does impose restraints in certain circumstances. The extent of these restraints varies according to the situation and to the disposition of the Government to recognize them.

2. The possibility of restraint only arises if the continuation of confidence in the Government is called into question. A defeat in the House preceding dissolution or a defeat at the polls would be the usual causes of restraint.

3. The restraint has been recognized as applying to important policy decisions and appointments of permanence and importance. Urgent and routine matters necessary for the conduct of government are not affected. ${ }^{26}$

\section{Conclusion}

The Manual of Official Procedure of the Government of Canada, like the British Precedent Book, was designed as a "practitioner's handbook", intended for use by senior civil servants who advise cabinet and work with the machinery of government, in addition to the prime minister and cabinet ministers themselves. These practitioner's handbooks compile historical precedents and provide justifications in a more exhaustive format, designed to present decision-makers with the relevant information required to make informed decisions. Their sheer bulk and technical nature, however, make them inaccessible to a general audience who would want to learn about parliamentary government.

In contrast, "cabinet manuals" like the British Cabinet Manual and the New Zealand Cabinet Manual are presented in shorter, more accessible formats, describing general principles and constitutional conventions of the parliamentary system and the basic roles and functions of its main components, rather than listing historical precedents that justify current positions. Lastly, "guidelines", provide brief statements of particular conventions on a specific topic or instruc- 
tions, like "directives", on a particular function and generally omit both historical precedents and broad descriptions of principle.

The Manual of Official Procedure of the Government of Canada represents an invaluable interpretation of constitutional conventions in its own right. It embodies the spirit of Westminster parliamentarism and exemplifies its principles: a harmonious balance between adaptability and continuity, an ethos of self-restraint, moral obligation, and respect for parliament and the constitution. However, the Manual does not "codify" constitutional conventions, which would require writing in statute or amending the Constitution Acts; instead, it amounts to an official interpretation of convention. The Manual combines the characteristics of the practitioner's handbook and the cabinet manual: it describes historical precedents in detail, from which it implies normative principles of parliamentarism, yet it describes and outlines potential courses of action rather than prescribing them, as a codified text would. The Manual of Official Procedure of the Government of Canada must, without doubt, be considered in any effort to produce another Canadian document on constitutional conventions.

\section{Notes}

* Nicholas MacDonald is an MPM candidate with the inaugural class of the Political Management programme at Carleton University.

James Bowden is an MA candidate with the Department of Political Studies at the University of Ottawa.

The authors thank Professor Adam Dodek of the University of Ottawa for his assistance in funding the electronic reproduction of the Manual from the Library and Archives of Canada, and are indebted to Paul Benoit for his invaluable insights throughout the production of this article. An electronic copy of the Manual of Official Procedure of the Government of Canada can be viewed online, in English only, at www.parliamentarism.ca.

1 "Government Formation in Canada Roundtables", online: Public Policy Forum <http://www. ppforum.ca/governmentformation>; "Adjusting to a New Era of Parliamentary Government", online: David Asper Centre for Constitutional Rights $<$ http://www.aspercentre.ca/Assets/
Asper+Digital+Assets/Events+and+Materials/ Constitutional+Conventions+Workshop/

Final+Report/report-english.pdf>.

2 Canada, Privy Council Office, Manual of Official Procedure of the Government of Canada (Ottawa: 1968) (Henry F Davis and André Millar), Ottawa Library and Archives Canada/National Archives of Canada/National Archives of Canada (subject files, vol. 516) at iii. Reproduced with the permission of the Minister of Public Works and Government Services Canada (2011).

3 Ibid.

$4 \quad$ Ibid.

5 It is worth noting that there is no French-language translation of the Manual. We speculate that this could be due to its considerable length, which would have necessitated a time-consuming translation, and that it was produced before the implementation of the Official Languages Act (1969), and was never published.

6 Reference re Secession of Quebec, [1998] 2 SCR 217 at para 32, 161 DLR (4th) 385 [Reference re Secession of Quebec].

7 Peter Aucoin, Mark D Jarvis \& Lori Turnbull, Democratizing the Constitution: Reforming Responsible Government (Toronto: Emond Montgomery Publications Ltd., 2011) at 80; Corbett Haselgrove Spurin, "Chapter 5: Constitutional Conventions" in Constitutional and Administrative Law (Corbett Haselgrove Spurin, 2004) at 3, online: The Nationwide Academy for Dispute Resolution (UK), Ltd. <http://www.nadr.co.uk/ articles/published/ConstitutionalLaw/Chapter005Conventions.pdf $>$.

8 Alexander Hamilton or James Madison, The Federalist Papers, No. 51: "The Structure of the Government Must Furnish the Proper Checks and Balances Between Different Departments." From the New York Packet, Friday, February 8 , 1788.

9 Reference re Secession of Quebec, supra note 5 at para 32.

$10 \quad$ Ibid at para 62.

11 Reference re Resolution to Amend the Constitution, [1981] 1 SCR 753 at 884, 125 DLR (3d) 1

[Patriation Reference].

12 Ibid at 883; Constitution Act, 1867 (UK), 30 \& 31 Vict, c 3, reprinted in RSC 1985, App II, No 5.

13 Patriation Reference, supra note 11 at 883-884.

14 Peter J Boyce, The Queen's Other Realms: The Crown and Its Legacy in Australia, Canada, and New Zealand (Annandale: The Federation Press, 2008) at 5.

15 Canada, Privy Council Office, Manual of Official Procedure of the Government of Canada (Ottawa: 
1968) (Henry F Davis and André Millar),

Ottawa, Library and Archives Canada/National

Archives of Canada (subject files, vol. 516) at 135.

Reproduced with the permission of the Minister of Public Works and Government Services

Canada (2011).

The Manual then provides the following foot-

note: W. Ivor Jennings, ed, Cabinet Government, 1st ed (Cambridge, 1947), at 35.

16 Ibid at 146. The Manual then provides the following footnote: $H$. of C. Debates, 30 June 1926 at 5217.

$17 \quad$ Ibid at 447.

$18 \quad$ Ibid at 448.

19 Ibid at 149.

20 Ibid at 150. The Manual provides the following footnote: J R Mallory, "Cabinets and Councils in Canada”, Public Law (Autumn 1957), at 231-251.

21 Ibid at 150.

22 Ibid at 401.

23 Ibid at 403.

24 Ibid at 407.

25 Ibid at 408-409.

26 Ibid at 89. 